\title{
Exit and Failure of Credit Unions in Brazil: A Risk Analysis
}

Flávio Leonel de Carvalho

Ph.D Professor, Department of Administration,- Federal University of São Carlos

Email: flavio@ufscar.br

Maria Dolores Montoya Diaz

Senior Lecturer, Department of Economics, School of Economics, Business, and Accounting, University of São Paulo

Email: dolores@pq.cnpq.br

Sigismundo Bialoskorski Neto

Full Profesșor, Department of Accounting, School of Economics, Business, and Accounting, Ribeirão Preto, University of São Paulo Email: sig@usp.br

Aquiles Elie Guimarães Kalatzis

Senior Lecturer, Department of Production Engineering, University of São Paulo

Email: aquiles@sc.usp.br

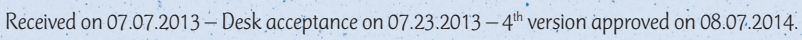

\section{ABSTRACT}

This study aims to investigate the factors that affect the market exit of Brazilian singular credit unions from 1995 to 2009 ; it also identifies and lists the determinants of various types of market exits and analyzes whether profitability is a significant factor for credit union survival. This study was conducted with accounting data provided by the Central Bank of Brazil, which derives only from individual cooperatives, i.e. singular credit unions. Quarterly financial statements from these credit unions that were active from 1995 to the second quarter of 2009 were employed, totaling 71,325 observations for 1,929 credit unions. Based on survival and the model of competing risks (such as the Cox, Exponential, Weibull, Gompertz, and Competing Risk models), the results show that there is no statistical evidence to ensure a correlation between profitability and credit union survival. The results also suggest that the size of credit unions plays a key role in their survival and longevity and that their funding and investment management are related to their survival and risk of market exit. In conclusion, the results confirm the initial idea that the duality inherent to credit unions - cooperative principles versus economic efficiency - might influence the stability, survival, and longevity of these institutions. Such results may also imply that a credit union embracing the rationale of a private bank will become more estranged from its members, something which will hinder its future operations and increase the likelihood of its exit from the market.

Keywords: Microcredit, Cooperatives, Efficiency, Survival, Longevity. 


\section{INTRODUCTION}

Credit unions in most Latin American countries constitute an important financial resource for many micro- and small enterprises and poor and working-class households (Westley \& Shaffer, 1999). Bauer, Miles and Nishikawa (2009) state that around $18.5 \%$ of the global working-age population were members of credit unions in 2007, according to the World Council of Credit Unions (WOCCU).

Furthermore, a credit union is managed by its own members; thus, most cooperatives fail in their early years due to market competition with banks in large cities. In these cases, credit unions lose the support and cash flow of their members, rural producers, and/or small entrepreneurs. This is a problem for governments and economic development policies in poor areas. Regarding our country, the Central Bank of Brazil (BACEN) has a special unit working with cooperatives and it has developed wide-range research projects and an agenda promoting good credit union governance and management, in order to prevent credit union failure, partly because credit unions fill the gaps of development policies in poor areas. Thus, this role is significant as a driver of public policies regarding credit unions in Brazil.

According to Baer and Nazmi (2000), Brazilian credit unions' share in the credit market increased around 11 points between 1993 and 1997. McKillop and Wilson (2011) claimed that there were over 49,330 credit unions in 98 countries, totaling over 184 million members in 2009, and these credit unions boasted around US\$ 1,354 billion in assets. According to the World Council of Credit Unions (2014), credit unions in Latin America enjoyed a penetration rate of $6.39 \%$ in 2012 . In Brazil, the economic importance of these institutions may also be illustrated by their figures: 494 credit unions were created between 2000 and 2008 (Soares \& Melo Sobrinho, 2008). It is worth emphasizing that the number of credit unions in Brazil decreased from 1,378 in 2008 to 1,318 in 2010, according to Banco Central do Brasil (2011). This decrease accounts for the net balance between new credit unions and the closure of existing credit unions, which has resulted in a negative balance over recent years. By contrast, the number of credit union members in Brazil increased from 1.5 million in 2002 to 5.1 million in 2010 (Banco Central do Brasil, 2011), something which indicates the social importance of credit unions in the market, notwithstanding the occasional failure.

In Brazil, the member-owner management of credit unions is characterized by low levels of professionalism and agency problems. According to Braga, Bressan, Colosimo and Bressan (2006), cooperatives in Brazil are sometimes created with almost no planning, something which leads to staffing deficiencies and an inadequate support structure; thus, cooperatives are exposed to damaging political interference and unbridled self-interest. Despite their importance to agribusiness development and poor urban areas, the number of credit unions has dropped due to failure problems.

The international literature recognizes failure problems in financial organizations and social organizations, but few studies have investigated the causes of discontinuity and failure regarding credit cooperatives. In Brazil, it is important to analyze the problems that contribute to credit union failure and discontinuity. Given the importance of the topic, this study resorts to accounting data to analyze the various types of credit union market, whose purpose is forecasting financial problems and proposing improvements to the control and monitoring mechanisms of these institutions.

All Brazilian singular credit unions linked to BACEN were analyzed, including the various categories of singular credit unions: rural credit unions, which are the largest ones and usually related to agricultural cooperatives; mutual credit unions, which are usually urban cooperatives, admitting members that belong to the same professional category; and free admission cooperatives, which admit members from any profession. The database used in this study was provided by BACEN; it contains accounting data from 1995 to the second quarter of 2009 , totaling 71,325 observations for 1,929 singular credit unions.

Despite the theoretical focus of studies on cooperatives' discontinuity and market exits, scholars have only a general idea about the factors that contribute to the exit of credit unions from the market; however, regarding cooperatives, such studies have not analyzed which factors are important and they do not address the consequences of market exits by credit unions. Thus, this study aims to identify any statistical association between the various financial ratios of singular credit unions with higher or lower probability of discontinuity. Fulfilling this objective, it may shed light upon which variables are important to look for in order to prevent the exit of credit unions.

In Brazil, there are few studies regarding credit unions. The only available statistical data is provided by BACEN. Perhaps, this is the first time that credit cooperatives have been the subject to determine which financial variables are relevant to the discontinuity process - after considering various types of exit - and this article introduces a discussion on why these variables are relevant. Thus, this study discusses a key academic topic in Brazil.

This article contributes to the international literature by analyzing how financial variables are considered in cooperatives, particularly in relation to synthesizing the cooperative principles of managing members' objectives and the organizational economic efficiency objectives, including investment and funding manage- 
ment, other revenue shares related to total revenue, and the size and nature of cooperatives. We examine the relation between financial ratios and the probabilities of various types of credit union discontinuities and market exits in Brazil. Our main results highlight that the model of competing risks revealed a significant difference in the determinants of various types of discontinuity, they showed that the size of a credit union is significantly related to its life expectancy and demonstrated that banking profitability, return on assets, and credit profitability are not significant in determining the pro- bability of market exit for these institutions. As a major implication of this research, we are able to punctuate the need for improving inter-cooperation and strengthening the current credit unions.

This article is organized as follows: in addition to this introduction, section 2 discusses the theoretical framework and research objectives, section 3 describes the methodology and models adopted, section 4 presents the results, section 5 discusses and analyzes the determinants of various types of credit union failures, and section 6 consists of our final remarks.

\section{LITERATURE REVIEW}

Although credit unions have grown in number and popularity in recent years, a significant number of credit unions have discontinued their operations. Different methods and approaches have been used to predict business failures and identify the relation of certain financial characteristics to the risk of company closure or failure. However, business failure may be analyzed in different ways, depending on the study objective and its approach. Generally, business failure may be defined as the fact that a company cannot pay its creditors, preferred shareholders, and suppliers or a situation involving some legal impediment to the operation of the institution that compromises business continuity (Dimitras, Zanakis, \& Zopounidis, 1996).

In the case of credit unions in Brazil, their continuity can be compromised or their activities can be discontinued when they enter into a process of judicial liquidation (receivership), extrajudicial liquidation, or suspension. Extrajudicial liquidation occurs when a cooperative voluntarily decides to terminate its activities. Judicial liquidation in relation to a financial institution refers to the economic intervention of the State in the business activities of a financial institution, which usually occurs when the continuity or discontinuity of this institution represents a risk to society with negative repercussions in the market. Suspension occurs when there is discontinuity of the activities of a credit union. Credit unions that have discontinued their activities for unknown reasons are referred to as "closed". Here, the only information available in the database indicates that a credit union was closed or cancelled; the specific cause of exit was not determined and/or is not revealed. Thus, this group may contain credit unions for which the cause of exit was failure and credit unions that were acquired by or merged into another company (something which does not necessarily represent failure, but it has been a major cause of credit union exit in Brazil since 2008).

Credit unions have grown in Brazil in recent years, and part of this growth stems from the development of
Brazilian agribusinesses, tax benefits, and the provision of financial services at lower costs. Credit unions are forced to expand their operations due to the need to increase their size and scale in financial markets, and many of these institutions have opted for mergers or incorporations. This common process has been observed in other countries and it has taken shape recently in Brazil. However, in this study, this factor cannot be analyzed. Among those credit unions that have started the process of exiting the market, it was not possible to identify those that were planning to merge or be acquired. Additionally, among credit unions that are classified as closed (i.e. an unknown type of failure), it was not possible to identify those that had pursued a merger.

Having these factors in mind, we have not found any study that explores the determinants of the various types of credit union market exit. Few studies have investigated the determinants of credit union failure and the number of studies that have addressed this phenomenon in developing countries is even smaller. Additionally, with computational progress, the employment of various statistical methodologies and the advance of empirical tools, the accuracy levels of prediction models for company closure have increased. Dimitras et al. (1996) argued that studies related to the closure of companies may be classified by country, industry, or method. However, few studies have investigated whether different reasons for the closure of credit unions are motivated by different factors.

The first studies to use accounting ratios to predict financial problems date from the early 1960s (Beaver, 1966; Altman, 1968; Libby, 1975). Some studies have indicated that the prediction of bank insolvency is feasible when accounting data are used (Albuquerque Junior \& Ribeiro, 2001; Ban \& Mazibas, 2009; Canbas, Cabuk, \& Kilic, 2005; Cole \& Gunther, 1998; Janot, 2001). Specifically regarding credit unions, we cite the studies of Barron, West and Hannan (1994), who investigated the relation between the growth and death of credit unions, and Desai, Conway, Crook and Overstreet (1997), who 
investigated the use of credit-scoring models in environmental credit unions using neural networks and genetic algorithms.

Using a hazard function, Goddard, McKillop and Wilson (2009) investigated the possibility of identifying the determinants of acquisition for credit unions by considering the role of technology. These researchers showed that acquisition hazard is inversely related to both asset size and profitability and positively related to liquidity. Another factor noticed was that institutions with low capitalization and those with small loan portfolios related to total assets are susceptible to acquisition and that cooperatives with constrained growth conditions are less attractive acquisition targets when compared to those with greater growth opportunities.

Regarding cooperatives - in which the planning, control, and execution processes should be defined in accordance with member-determined guidelines - accounting information assumes a democratizing, transparent, and supportive role in collective participation. In this context, Gimenes and Uribe-Opazo (2006) tested the use of accounting information in the process for monitoring and forecasting the deterioration of financial ratios of rural cooperatives and concluded that using such data allows forecasting financial distress. Evaluating the economic situation of rural credit unions from Minas Gerais, Brazil, Braga et al. (2006) showed that it is possible to obtain the information needed to monitor these institutions. Ferreira, Gonçalves and Braga (2007) used data envelopment analysis and the Tobit method to investigate the determinants of the efficiency of these entities and found evidence that credit unions often do not use their resources efficiently.

Davis (2001) investigated the importance of the relation between the principle "one member, one vote" to the survival of credit unions, arguing that as older members have greater participation in funds, they have greater incentives to attempt extracting the maximum benefits by transforming these institutions into for-profit corporations. However, the presence of new members and the existence of some one member/one vote rule inhibit this possibility and contribute to the survival and continuity of the institution as a cooperative.

There is a duality in the management of cooperatives: on the one hand, there are cooperative principles and, on the other hand, the market and competition impose certain requirements. Thus, through democratic management, these institutions must be efficient and productive to ensure their survival without abandoning their principles. This duality in the management model has resulted in many cooperatives exercising merger or incorporation options.

For instance, Ralston, Wright and Garden (2001) cited the American and Australian credit unions that have attempted to increase in size, scale, and efficiency through mergers. The ability of merged credit unions to provide better services is noticed by their members. However, not all institutions experiencing this process have improved their performance (Fried, Knox Lovell, \& Eeckaut, 1993), although many have shown gains in scale and size. Further research is needed to determine the reasons why credit unions that have undergone incorporation or merger processes experience different effects on performance. Ralston et al. (2001) corroborated that assertion and observed that mergers are not associated with subsequent improvements in efficiency.

An important characteristic of credit unions is the relation between operational and social efficiency within these institutions. Such institutions are created as extensions of their members' economies and aim to provide them with financial services (Barroso \& Bialoskorski Neto, 2010). User-owners have the power to determine both the amount of fees and the returns distributed to members as a share of surplus. Fees are likely to be lower, because the cooperative members are those who will bear their immediate cost. At the end of the period, a percentage of the surplus generated will be distributed, and the general meeting of the cooperative will be responsible for determining the percentage of the retained and distributed surplus. This responsibility is one of the main characteristics of these institutions that influence their financial and social performance as well as their survival. According to Gutiérrez-Nieto, Serrano-Cinca and Mar Molinero (2009), microfinance institutions constitute a special type of financial institution, because they have both financial and social roles and should be efficient in both.

A cooperative may be regarded as financially and operationally ineffective, with low fees and high shares of surplus, and simultaneously efficient from the social perspective, because it can generate social benefits and services with lower fees and higher shares of surplus. However, the main challenge in managing these institutions is finding the optimal fees and surplus shares that enable financial soundness to guarantee their social benefits without endangering their continuity.

Considering these factors, Barroso and Bialoskorski Neto (2010) analyzed the share of surplus process from the largest credit unions in the state of São Paulo and noticed that the largest cooperatives distribute a considerable part of their surpluses in current accounts (i.e. on deposit) with the possibility of immediate use. Medium-sized cooperatives return most of the surplus by transforming it into equity, something which depends on the joint resolutions to be used. Smaller cooperatives retain most of the surplus as indivisible funds. According to the authors, the results suggest that using threshold decision-making in relation to the generation and distribution of surplus may be considered as a mechanism for attracting members (i.e. the distribution decisions are related to a management system that aims to encourage activity and member participation in cooperatives).

In Brazil, national legislative changes have been made since 2003, in order to stimulate the development of microcredit and to encourage credit unions to participate in the microcredit market; these changes have resulted in an increase in the number of new credit unions. According 
to Trindade, Ferreira Filho and Bialoskorski Neto (2010), an outstanding feature of the Brazilian economy after its stabilization in the second half of the 1990s was the decreased number of multiple banks and the increased number of credit unions. This result was primarily due to the various strategies adopted by these institutions. Whereas many banks opted for an aggressive strategy of mergers and acquisitions, which was marked by the privatization of public banks in Brazil, credit unions were primarily characterized by organic growth. The merger option became more common only from 2008 on.

Several studies have investigated the effects of age, technological intensity, performance, investment in research and development, exports and other factors (such as human capital, legal structure, and foreign capital) on the survival of companies. There are numerous causes for credit union closure, but few studies have analyzed these issues in underdeveloped or developing countries, according to Esteve-Pérez, Sanchis-Llopis and Sanchis-Llopis (2010).

Credit unions that are more efficient play their socioeconomic role better, something which results in the promotion of financial disintermediation, the ability to generate surpluses, and an increased volume of credit granted (Braga et al., 2006). The literature indicates that operational efficiency is a determining factor for the continuity of businesses. In credit unions, whose central objective is not profit, efficiency is even more important than in other institutions. Thus, the need for restructuring, cost reduction, and the assignment of loans under better conditions requires a high level of professionalism and organization.

Although the stimulus to the development of credit unions assigns them the role of contributing to fight and reduce poverty (Fuller, 1998), few studies have addressed the financial management process in these institutions and the effects of financial management on their survival, according to Ferguson and McKillop (2000).

When analyzing the performance of credit unions, the inherent features of these institutions must be considered. In credit unions, surplus is generated by operations with members and it is referred to as leftovers or residuals. These leftovers are reinvested in credit unions or returned to members according to the volume of a credit union's operations, transactions, and deposits in the cooperative. Doctrinally, profit does not exist, because the concept of profit is related solely to the remuneration of capital, and leftovers in a cooperative are distributed according to the volume of transactions of its members.

According to Taylor (1979), a cooperative firm has no independent goals of its own; instead, it seeks to further the interests of its membership. Moreover, Taylor (1979) claims that credit unions try to pay the highest rate on savings and charge the lowest rate on loans. According to Spencer (1996), this characteristic shows a crucial difference between credit unions and financial institutions. Credit unions may generate a conflict between members - borrowers seeking low interest rates and savers seeking satisfactory dividend rates (Spencer, 1996). Bressan, Braga, Resende Filho and Bressan (2013) investigated whether the characteristics of members that dominate a credit union determine the way it allocates monetary value.

Despite these remarkable characteristics, these institutions must be efficient and profitable, as the surplus is related to the efficient use of resources and ensures that these institutions keep playing their social role. In this context, this study considers the relation between surplus and certain figures, such as total assets or net equity, as a measure of profitability. Given the importance of profitability, we investigate if there is a positive or negative relation between profitability and the survival of credit unions in Brazil.

The literature suggests that size is one of the most important factors to consider when analyzing the performance of companies. Larger firms enjoy the benefits of economies of scale and scope, they are stronger, more resilient, and tend to be more diversified (Gu, Lee, \& Rosett, 2005). This variable may be measured by various proxies: total sales revenue, total assets, equity, market value of shares, and the number of employees, among others. Regarding credit unions, the size measured by the natural logarithm of total asset value seems to be more appropriate, because these institutions do not have income, they do not trade shares and have non-negotiable shares. The number of employees is not an appropriate measure, as labor and management are largely performed by the members of cooperatives. Thus, this study investigates whether the size of a credit union is associated with lower or higher probability of discontinuity.

As any institution in the financial system, credit unions raise funds from surplus agents (i.e. members) and lend them to deficit agents (who are also members). Such a situation requires the establishment of an optimal rate to remunerate the surplus members without overly burdening deficit members, while also ensuring the maintenance of operational activities, reducing the risks of operations, and covering the costs of intermediation. Accounting indicators were employed to relate these figures to the operational situation and to analyze the relation between funding and investment in credit unions. Thus, other aspects were analyzed to determine whether funding and investment management are related to longevity.

Another important factor is that the activity of credit unions may be discontinued due to various reasons. It is possible to assume that different types of discontinuity judicial liquidation, extrajudicial liquidation, suspension, or closure - result from different factors and that organizational and financial factors affect outputs differently. So, this study investigates the factors that cause different types of market exits, i.e. whether the effect of financial variables on failure depends on the type of output.

Finally, it is clear that the main objective of this research was conducting an exploratory analysis on the potential determinants of singular credit union longevity and survival. In addition, this article aims to verify 
the association between financial ratios and the risk of discontinuity to contribute to future theoretical models on the operation of singular credit unions. This way, we may list profitability, size, funding, and investment management as potential determinants of credit union longevity to be investigated herein.

\section{EMPIRICAL STRATEGY AND DATA}

This research addressed Brazilian singular credit unions and the accounting data analyzed were provided by BACEN. We resorted to these data because of the number of credit unions supervised by BACEN and their diversity regarding both type and geographical region. Data comprise rural, mutual, and free admission singular credit unions. Quarterly financial statements of credit unions that were active from 1995 to the second quarter of 2009 were used and they initially totaled 71,325 observations for 1,929 singular credit unions. BACEN also provided a spreadsheet containing the national codes of cooperatives, as well as data regarding their legal status and event dates. The financial ratios shown in Table 1 were based on quarterly financial statements for each quarter from 1995 to the second quarter of 2009; thus, data for the second quarter of 2009 were considered as the end data. The credit unions that were not active on this date were considered as discontinued. Based on additional spreadsheets provided by BACEN, it was possible to identify whether the discontinuity credit union is related to extrajudicial liquidation, judicial liquidation, or suspension. Discontinued singular credit unions whose discontinuity was unknown were classified as closed.

The evaluation of business discontinuity by means of accounting data and ratios using various indicators of economic and financial performance has frequently been performed (Barron et al., 1994; Davis, 2001; Bhattacharjee, Higson, Holly, \& Kattuman, 2009; Liu, 2009), but studies addressing the determinants of credit union failure are scarce. Thus, this study aims to investigate whether different types of credit union discontinuity are determined by different factors and which issues increase or decrease the mortality of these institutions.

This article has the following specific objectives: (a) investigate the economic performance indicators of financial institutions and their suitability for credit unions; (b) select the variables to be used; (c) analyze the key factors related to the mortality of credit unions in Brazil; (d) determine which statistical models are best suited to our objectives; and (e) identify the factors that have prompted the discontinuity of operations of credit unions in Brazil. In this case, we may propose a methodological roadmap to develop this study, for which we provide the details in the next section: (1) calculating financial ratios and identifying closed cooperatives in 2009; (2) developing descriptive statistics of financial ratios and performing two-sample $t$ tests; (3) performing a univariate analysis for continuous variables and the initial identification of important variables; (4) using a Cox regression to determine the significance of variables; (5) investigating suitable statistical models for discontinuity analysis; and (6) using a risk analysis model to determine different types of market exit.

\subsection{Performance indicators of financial institutions}

The database provided by BACEN contained accounting data categorized according to the Chart of Accounts of the Brazilian Financial System (COSIF). Based on this chart, we computed the indicators (Table 1) of economic and financial performance. Three binary variables were defined for each type of institution (Table 1): Rural, Free Admission and Mutual Credit Unions.

Table 1 shows each indicator used and its calculation method.

Table 1

Variables used in the study

\begin{tabular}{l|c}
\hline Variable & Calculation formula \\
\hline Leverage & Debt / Equity \\
\hline Investments in Credit Operations & Credit Assets / Operating Assets \\
\hline Treasury Investments & Treasury / Operating Assets \\
\hline Other Operating Costs & Administrative Expenses / Operating Assets \\
\hline Voluntary Coverage & Cash / Real Liabilities \\
\hline Short-Term Funding & Current Liabilities / Debt \\
\hline Funding by Time Deposits & Time Deposits / Debt \\
\hline Funding by Demand Deposits & Short-Term Demand Deposits / Debt \\
\hline Structural Costs & Structural Expenses / Operating Assets \\
\hline Floating Funding & Liabilities without Cost / Debt \\
\hline Capitalization & Equity / Debt \\
\hline Coverage with Services & Services Revenue / Structural Expenses \\
\hline cont. &
\end{tabular}




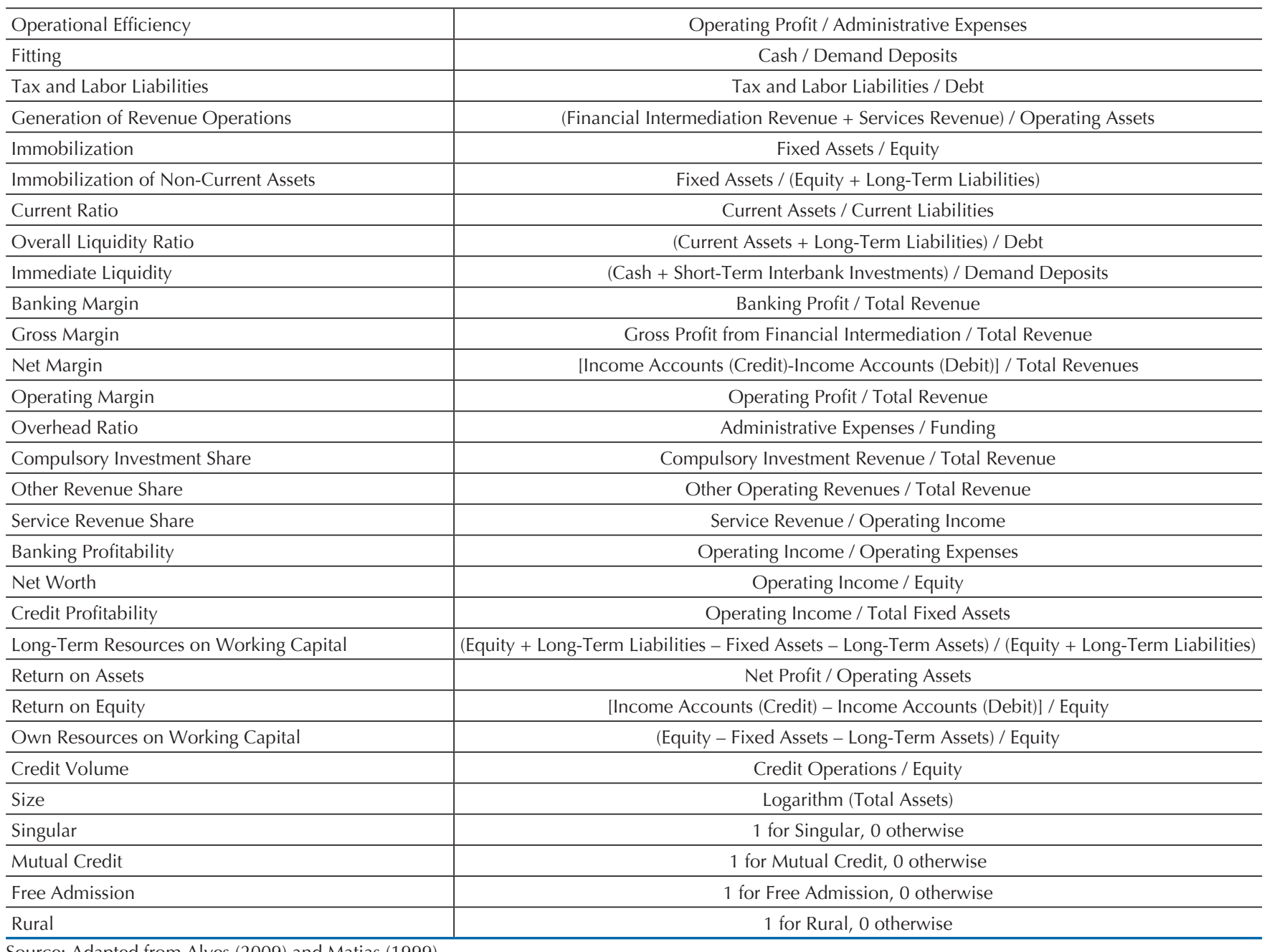

\subsection{Selection of variables to be used}

Bruin (2006) indicated that we must examine each variable individually prior to beginning a survival analysis. For determining the main economic and financial indicators to be retained in this study, we used the methodology proposed by the author (i.e. a Kaplan-Meier survival analysis) for all categorical variables and used the Cox proportional hazards model for the continuous variables before initiating the statistical modeling. The Cox model is often used in the analysis of survival data and its versatility has turned it into the most commonly used model in clinical studies (i.e. medical studies).

This study employed financial figures prior to the closure of credit unions and the financial data of credit unions that were active by the end of 2009. To assess the factors related to the discontinuity of credit unions, the following models were used: Cox regression models, the Exponential model, the Weilbul model, the Gompertz model, parametric models, and the model of competing risks.

The key concept in survival analysis is the hazard rate $h(t)$, which is also known as the conditional failure rate. It is the (limiting) probability that the failure event occurs in a given interval, conditional upon the subject having survived to the onset of that interval, divided by the interval width. The relation between the hazard function and the survival function is as follows (Cleves, Gould, Gutierrez, \& Marchenko, 2010):

$$
h(t)=\frac{f(t)}{S(t)}
$$

where $f(t)$ is the density function and $S(t)$ is the survival function.

The Cox proportional hazards regression model asserts that the hazard rate for the $j t h$ subject in the data is as follows (Cleves et al. 2010):

$$
h\left(t \mid x_{j}\right)=h_{0}(t) \exp \left(x_{j} \beta_{x}\right)
$$

where $h_{0}(t)$ is the baseline hazard that can be left unparameterized, $x_{\mathrm{j}}$ are the control variables related to exit of credit unions detailed in section 3.3 and $\beta_{x}$ are the parameters to be estimated.

In the parametric models, a functional form for $h_{0}(t)$ is specified. The exponential model assumes $h_{0}(t)=\exp (a)$ for some $a$. The Weibull model assumes $h_{0}(t)=p t^{p-1} \exp (a)$, and the Gompertz model assumes $h_{0}(t)=\exp (a) \exp (\gamma t)$.

Broadly speaking, we may claim that the model of competing risks is appropriate for modeling a situation in which different events can lead to the exit of credit unions. The discontinuity of credit unions is the event of interest, but the causes of such discontinuity may be extrajudicial liquidation, judicial liquidation (i.e. types of failure), suspension, or an unknown exit reason 
(termed "closed" in this paper), which includes both failures and merger/incorporation. To better understand the aspects involved in the discontinuity of credit unions, different combinations of the possibilities were associated with the event of interest and with the competitive events.

Following Cleves et al. (2010), the competing-risks regression estimated here assumes $\bar{h}_{i}(t \mid x)=\bar{h}_{i, 0}(t) \exp (x \beta)$ , where $\bar{h}_{i}(t \mid x)$ is the sub-hazard function for failure cause $i$ and $\bar{h}_{i, 0}(t)$ is the baseline sub-hazard function, both developed by Fine and Gray (1999). This specification is analogous to Cox regression, with sub-hazards taking the place of traditional hazard functions.

According to Cleves et al. (2010: 382), "the sub-hazard for cause $i$ is the instantaneous probability of failure from cause $i$ at time $t$ given either no failure before $t$ or failure from another cause before $t$ ".

We estimated three specifications considering different exit events (Closed; Closed and Suspended; Judicial Liquidation and Extrajudicial Liquidation) and corresponding competing events (Suspended, Judicial Liquidation and Extrajudicial Liquidation; Judicial Liquidation and Extrajudicial Liquidation; Closed and Suspended).

The model was estimated with the dependent variable indicating the difference in days between the date of discontinuity of the credit union and the date of its creation or the difference in days between the end date of the database and the date of the credit union's creation. Failure was represented by an indicator variable given a value 1 if cooperative activities had been discontinued and 0 otherwise. In addition, the financial indicators were used as control variables.

It is worth noticing that the observations related to credit unions that remained in operation at the end of the analysis were regarded as censored observations, given that the exact duration of these credit unions remains unknown. It is known that such credit unions have kept operating at least for a specified number of days and that the presence of censorship is crucial in duration models. Therefore, it was possible to identify singular credit unions that were active or closed (discontinued) in 2009. Thus, some descriptive statistics and mean comparison $t$ tests are shown in Table 2. For p-values lower than 0.10 (last column), it was not possible to reject the null hypothesis that there is no difference between the two means (active and discontinued singular credit unions). This analysis demonstrates that 21 out of the 38 financial ratios exhibited mean values that are statistically similar.

Initially, in order to assess which variables among the 38 originally submitted should be retained for the analysis, we used the estimator for categorical variables proposed by Kaplan and Meier (1958). In this method, the probability of survival until the specified date is estimated by assuming that survival until each time is independent of survival until other times. Therefore, we observed that as the duration of the credit union increases, there is a decrease in the expectation of survival and an increase in the possibility of failure (interruption/discontinuity/exit).

The analysis of continuous variables was performed using the Cox proportional hazards model. The variables whose $p$-values were above $20 \%$ were removed from the next steps of the analysis, and other variables were retained as potential explanatory variables. Out of the 38 variables initially examined, 21 showed a type 1 error probability above $20 \%$ and they were removed from the next analysis; 17 continuous variables remained.

Table 2 shows the mean and standard deviation (SD). The column defined as "All" contains descriptive statistics for all singular credit unions. The column defined as "Discontinued" contains discontinued credit union data. And the column classified as "Active" contains information regarding credit unions that were in operation in the last quarter analyzed, in 2009.

Descriptive statistics and mean two-sample t test

\begin{tabular}{|c|c|c|c|c|c|c|c|}
\hline \multirow{2}{*}{$\begin{array}{l}\text { Credit Union } \\
\text { Variable }\end{array}$} & \multicolumn{2}{|c|}{ All } & \multicolumn{2}{|c|}{ Discontinued } & \multicolumn{2}{|c|}{ Active } & \multirow{2}{*}{$\frac{\text { t test }}{\text { p-value }}$} \\
\hline & Mean & SD & Mean & SD & Mean & SD & \\
\hline Leverage $(\mathrm{AL})$ & $-2 . E+01$ & $9 . \mathrm{E}+03$ & $-2 . E+01$ & 1.E+04 & 1.E+01 & $3 . \mathrm{E}+02$ & 0.690 \\
\hline Investments in Credit Operations & 0.322 & 0.222 & 0.311 & 0.208 & 0.382 & 0.276 & 0.000 \\
\hline Treasury Investments (APT) & 0.059 & 0.134 & 0.050 & 0.115 & 0.103 & 0.200 & 0.000 \\
\hline Other Operating Costs (CAD) & -0.014 & 1.037 & -0.005 & 0.098 & -0.058 & 2.545 & 0.000 \\
\hline Voluntary Coverage (CBV) & $9 . \mathrm{E}+01$ & $1 . E+04$ & $9 . \mathrm{E}+01$ & $1 . \mathrm{E}+04$ & $1 . \mathrm{E}+02$ & $6 . \mathrm{E}+03$ & 0.882 \\
\hline Short-Term Funding (CCP) & 0.322 & 5.132 & 0.309 & 5.217 & 0.386 & 4.666 & 0.144 \\
\hline Funding by Demand Deposits (CDVP) & 0.060 & 0.728 & 0.058 & 0.265 & 0.071 & 1.701 & 0.071 \\
\hline Structural Costs (CES) & -0.627 & 1.E+02 & -0.029 & 0.118 & -3.661 & $3 . \mathrm{E}+02$ & 0.007 \\
\hline Floating Funding (CFL) & 0.253 & 0.930 & 0.244 & 0.573 & 0.301 & 1.905 & 0.000 \\
\hline Capitalization $(\mathrm{CL})$ & $4 . \mathrm{E}+02$ & $6 . \mathrm{E}+04$ & $5 . \mathrm{E}+02$ & 7.E+04 & $2 . \mathrm{E}+02$ & $1 . \mathrm{E}+04$ & 0.726 \\
\hline Coverage with Services (CS) & -1.170 & $3 . \mathrm{E}+02$ & -1.369 & $3 . \mathrm{E}+02$ & -0.134 & 0.766 & 0.647 \\
\hline Operational Efficiency (EFO) & $-2 . E+01$ & $4 . \mathrm{E}+03$ & $-2 . E+01$ & $4 . \mathrm{E}+03$ & $-2 . E+01$ & $7 . \mathrm{E}+02$ & 0.842 \\
\hline Fitting (EN) & $1 . \mathrm{E}+03$ & $8 . \mathrm{E}+04$ & $1 . E+03$ & $8 . \mathrm{E}+04$ & $6 . \mathrm{E}+02$ & $2 . \mathrm{E}+04$ & 0.495 \\
\hline Generation of Revenue Operations & 0.140 & 1.E+01 & 0.061 & 0.085 & 0.537 & $3 . \mathrm{E}+01$ & 0.000 \\
\hline Immobilization (IM) & -0.081 & $9 . \mathrm{E}+01$ & -0.214 & $1 . \mathrm{E}+02$ & 0.592 & 2.E+01 & 0.392 \\
\hline Immobilization of Non-Current Assets & -0.151 & $9 . \mathrm{E}+01$ & -0.237 & 1.E+02 & 0.280 & 6.841 & 0.581 \\
\hline Current Ratio (LC) & $6 . \mathrm{E}+02$ & $6 . \mathrm{E}+04$ & $7 . \mathrm{E}+02$ & $7 . \mathrm{E}+04$ & $5 . \mathrm{E}+02$ & $2 . E+04$ & 0.752 \\
\hline
\end{tabular}




\begin{tabular}{|c|c|c|c|c|c|c|c|}
\hline Overall Liquidity Ratio (LG) & 4.E+02 & $6 . \mathrm{E}+04$ & $5 . \mathrm{E}+02$ & 7.E+04 & $2 . \mathrm{E}+02$ & $1 . \mathrm{E}+04$ & 0.733 \\
\hline Immediate Liquidity (LI) & 8.E+01 & 9.E+03 & 8.E+01 & 9.E+03 & 1.E+02 & $6 . \mathrm{E}+03$ & 0.785 \\
\hline Banking Margin (MAB) & 0.932 & 0.125 & 0.938 & 0.107 & 0.900 & 0.193 & 0.000 \\
\hline Gross Margin (MB) & $-1 . E+02$ & $8 . \mathrm{E}+03$ & $-6 . E+01$ & $6 . \mathrm{E}+03$ & $-6 . E+02$ & $2 . \mathrm{E}+04$ & 0.000 \\
\hline Net Margin $(\mathrm{ML})$ & $-1 . \mathrm{E}+02$ & $8 . \mathrm{E}+03$ & $-6 . E+01$ & $6 . \mathrm{E}+03$ & $-6 . E+02$ & $2 . \mathrm{E}+04$ & 0.000 \\
\hline Operating Margin (MO) & -2.576 & $5 . \mathrm{E}+02$ & 0.504 & 3.283 & $-2 . E+01$ & 1.E+03 & 0.000 \\
\hline Overhead Ratio (OR) & $-2 . E+01$ & $2 . \mathrm{E}+03$ & $-2 . E+01$ & $3 . \mathrm{E}+03$ & $-5 . E+01$ & $2 . \mathrm{E}+03$ & 0.187 \\
\hline Compulsory Investment Share (PRAC) & 0.004 & 0.039 & 0.003 & 0.035 & 0.004 & 0.054 & 0.009 \\
\hline Service Revenue Share (PRS) & 0.055 & 0.099 & 0.051 & 0.083 & 0.074 & 0.154 & 0.000 \\
\hline Banking Profitability (RAB) & -0.537 & 1.E+02 & 0.008 & 0.144 & -3.296 & $3 . \mathrm{E}+02$ & 0.014 \\
\hline Return on Equity (RAD) & -1.236 & $3 . \mathrm{E}+02$ & -1.455 & $4 . \mathrm{E}+02$ & -0.126 & 5.295 & 0.694 \\
\hline Credit Profitability (RCR) & 0.169 & $2 . \mathrm{E}+02$ & 0.274 & 1.E+01 & -0.360 & 4.E+02 & 0.705 \\
\hline Long-Term Resources on Working Capital (RLPG) & 0.686 & 92.741 & 0.729 & $1 . \mathrm{E}+02$ & 0.464 & 8.633 & 0.777 \\
\hline Return on Assets (ROA) & -0.538 & $1 . \mathrm{E}+02$ & 0.006 & 0.144 & -3.297 & $3 . \mathrm{E}+02$ & 0.014 \\
\hline Net Worth (ROE) & -1.246 & $3 . \mathrm{E}+02$ & -1.465 & $4 . \mathrm{E}+02$ & -0.136 & 5.662 & 0.695 \\
\hline Credit Volume (VCR) & -8.072 & $3 . \mathrm{E}+03$ & $-1 . E+01$ & $3 . \mathrm{E}+03$ & 2.328 & 2.E+01 & 0.654 \\
\hline Size (SIZE) & $2 . E+01$ & $2 . \mathrm{E}+00$ & $2 . \mathrm{E}+01$ & $2 . E+00$ & $2 . E+01$ & $3 . \mathrm{E}+00$ & 0.000 \\
\hline
\end{tabular}

The results shown in Table 3 allowed us to select the continuous variables to be used in this study. Therefore, it was possible to select the important variables to be employed in the next step of this study, which aimed to determine the factors related to the discontinuity of these institutions. Through the comparison analysis shown in Table 3 to the means test shown in Table 1, it is possible to observe that, although the variables rela- ted to profitability (Gross Margin, Operating Margin, Overhead Ratio, Banking Profitability, Return on Asset) have significantly different mean values, they were not related to likelihood of survival.

Table 3 shows the results from the Cox proportional hazard model with a single continuous predictor. The objective of this step was selecting the most relevant variables.

Table 3

Univariate analysis for continuous variables

\begin{tabular}{|c|c|c|c|c|}
\hline Variable & Coefficient & Std. Err. & $\mathbf{P}>|\mathbf{z}|$ & Result \\
\hline Leverage $(\mathrm{AL})$ & $1.50 \mathrm{E}-06$ & 0.0300 & 0.9770 & Excluded \\
\hline Investments in Credit Operations (APOC) & $-1.4 \mathrm{E}+00$ & -6.6400 & 0.0000 & Retained \\
\hline Treasury Investments (APT) & $1.3 \mathrm{E}+00$ & 7.6700 & 0.0000 & Retained \\
\hline Other Operating Costs (CAD) & $-3.8 \mathrm{E}-02$ & -6.7700 & 0.0000 & Retained \\
\hline Voluntary Coverage (CBV) & $-5.3 \mathrm{E}-05$ & -0.3300 & 0.7420 & Excluded \\
\hline Short-Term Funding (CCP) & $1.5 \mathrm{E}-03$ & 0.4000 & 0.6860 & Excluded \\
\hline Funding by Time Deposits (CDP) & $-2.3 \mathrm{E}-01$ & -4.8800 & 0.0000 & Retained \\
\hline Funding by Demand Deposits (CDVP) & 7.3E-02 & 3.3900 & 0.0010 & Retained \\
\hline Structural Costs (CES) & $-2.8 \mathrm{E}-05$ & -0.3000 & 0.7620 & Excluded \\
\hline Floating Funding (CFL) & $6.4 \mathrm{E}-02$ & 2.3700 & 0.0180 & Retained \\
\hline Capitalization $(\mathrm{CL})$ & $-6.2 \mathrm{E}-05$ & -0.5900 & 0.5580 & Excluded \\
\hline Coverage with Services (CS) & $2.9 \mathrm{E}-03$ & 0.1900 & 0.8480 & Excluded \\
\hline Operational Efficiency (EFO) & $9.2 \mathrm{E}-05$ & 0.1900 & 0.8470 & Excluded \\
\hline Fitting (EN) & $-9.9 \mathrm{E}-05$ & -0.7300 & 0.4630 & Excluded \\
\hline Tax and Labor Liabilities (ETT) & $9.5 \mathrm{E}-04$ & 0.1800 & 0.8540 & Excluded \\
\hline Immobilization (IM) & $8.4 \mathrm{E}-04$ & 0.5000 & 0.6180 & Excluded \\
\hline Immobilization of Non-Current Assets (IMR) & $2.6 \mathrm{E}-02$ & 4.9600 & 0.0000 & Retained \\
\hline Current Ratio (LC) & $-2.2 \mathrm{E}-05$ & -0.4500 & 0.6540 & Excluded \\
\hline Overall Liquidity Ratio (LG) & $-6.1 \mathrm{E}-05$ & -0.5700 & 0.5710 & Excluded \\
\hline Immediate Liquidity (LI) & $-6.7 \mathrm{E}-05$ & -0.3200 & 0.7460 & Excluded \\
\hline Banking Margin (MAB) & $-7.3 \mathrm{E}-01$ & -3.5500 & 0.0000 & Retained \\
\hline Gross Margin $(\mathrm{MB})$ & $-1.3 \mathrm{E}-06$ & -0.4700 & 0.6410 & Excluded \\
\hline Net Margin $(\mathrm{ML})$ & $-1.3 \mathrm{E}-06$ & -0.4700 & 0.6420 & Excluded \\
\hline Operating Margin (MO) & $1.3 \mathrm{E}-05$ & 0.0600 & 0.9550 & Excluded \\
\hline Overhead Ratio (OR) & $-6.7 \mathrm{E}-06$ & -1.5400 & 0.1240 & Retained \\
\hline Compulsory Investment Share (PRAC) & $1.2 \mathrm{E}+00$ & 1.9800 & 0.0480 & Retained \\
\hline Other Revenue Share (PRORO) & $1.3 \mathrm{E}+00$ & 8.9600 & 0.0000 & Retained \\
\hline Service Revenue Share (PRS) & $2.0 \mathrm{E}+00$ & 8.3400 & 0.0000 & Retained \\
\hline Banking Profitability (RAB) & $-3.9 \mathrm{E}-06$ & -0.0300 & 0.9780 & Excluded \\
\hline Return on Equity (RAD) & $-1.2 \mathrm{E}-05$ & -0.0600 & 0.9510 & Excluded \\
\hline Return on Assets (ROA) & $-3.8 \mathrm{E}-06$ & -0.0300 & 0.9790 & Excluded \\
\hline Net Worth (ROE) & $-1.2 \mathrm{E}-05$ & -0.0600 & 0.9550 & Excluded \\
\hline Own Resources on Working Capital (RPG) & $5.5 \mathrm{E}-05$ & 0.1000 & 0.9200 & Excluded \\
\hline Credit Volume (VCR) & 1.3E-06 & 0.0200 & 0.9840 & Excluded \\
\hline Size (SIZE) & $-2.5 \mathrm{E}-01$ & -16.6000 & 0.0000 & Retained \\
\hline
\end{tabular}

Source: Prepared by the authors. 


\subsection{Definition of significant variables to measure discontinuity}

Based on the univariate analysis shown in Table 2, the Cox regression was estimated with all continuous variables whose $\mathrm{p}$-values were below $20 \%$. Table 4 shows the Cox regression model including all significant variables, excepted binary variables that represent the type of credit union (Mutual Credit, Free Admission, or Rural).

Table 4 shows Cox Regression. The first column presents the name of the variables. The second column presents the variable coefficient estimated. The third column presents the standard errors. The fourth column shows the p-values. And the last column shows the decision to retain or exclude the variable.

Table 4 Cox regression to determine the use of variables (Cox Preliminary)

\begin{tabular}{|c|c|c|c|c|}
\hline Cox Preliminary & Coefficient & Std. Err. & p-value & Result \\
\hline Investments in Credit Operations (APOC) & 0.1817 & 0.0475 & 0.0000 & Retained \\
\hline Treasury Investments (APT) & 0.6648 & 0.2030 & 0.1810 & Retained \\
\hline Other Operating Costs (CAD) & 0.6289 & 0.2108 & 0.1670 & Retained \\
\hline Funding by Time Deposits (CDP) & 0.6430 & 0.0849 & 0.0010 & Retained \\
\hline Funding by Demand Deposits (CDVP) & 0.7226 & 0.0568 & 0.0000 & Retained \\
\hline Generation of Revenue Operations (GOR) & 0.9658 & 0.0250 & 0.1790 & Retained \\
\hline Immobilization of Non-Current Assets (IMR) & 1.0333 & 0.0134 & 0.0110 & Retained \\
\hline Banking Margin (MAB) & 5.1426 & 2.7284 & 0.0020 & Retained \\
\hline Overhead Ratio (OR) & 1.0000 & 0.0000 & 0.0900 & Retained \\
\hline Compulsory Investment Share (PRAC) & 0.5812 & 0.9328 & 0.7350 & Excluded \\
\hline Service Revenue Share (PRS) & 22.5640 & 12.5048 & 0.0000 & Retained \\
\hline Long-Term Resources on Working Capital (RLPG) & 1.0077 & 0.0105 & 0.4580 & Excluded \\
\hline Size (SIZE) & 0.7242 & 0.0164 & 0.0000 & Retained \\
\hline
\end{tabular}

Source: Prepared by the authors.

We observed that Compulsory Investment Share (PRAC) and Long-Term Resources on Working Capital (RLPG) had no likelihood of a type 1 error above $20 \%$, so they were removed from the subsequent models. Therefore, the third specific objective (i.e. the analyses of the main factors related to the mortality of credit unions in Brazil) was fulfilled, and we were able to identify 13 continuous variables represented by economic and financial indicators that can be related to the likelihood of discontinuity for these institutions. At this stage, we used the Cox model, and its results were classified as Cox Preliminary (Table 4). The final discontinuity models (Table 5) included the variables retained from the Cox Preliminary Model and dummies variables that represent the type of credit union.

\subsection{Investigation of suitable statistical models for discontinuity analysis}

After conducting the univariate analysis and identifying the potential explanatory continuous variables for the likelihood of discontinuity of credit unions, we used the Cox proportional hazards model, identified as Cox Preliminary, to identify the determinants of the closure of credit unions. The final Cox model and all other models were estimated having the Cox Preliminary model as a basis. Table 5 compares the statistically significant variables in each parametric model studied. The models showed consistency between statistically significant variables and the direction of their respective effects.
A dummy variable was created for each type of credit union, and the variable for rural credit union was excluded, because this variable was regarded as the comparison dummy variable. The models estimated and shown in Tables 5 and 6 include these binary variables.

Table 5 includes the results of the Akaike Information Criterion (AIC), which was used to identify the most appropriate model for the purposes of this study. By adopting the model with the smallest AIC, we noticed that the Weibull model provided the worst results (AIC was 1.722). At this stage, the parametric Gompertz and exponential models showed an intermediate level of AIC, whereas the highest AIC levels were presented by the Cox Final (5.387) and Competing Risk models (4.816).

The models presented in Table 5 (the Cox, Exponential, Weibull, Gompertz, and Competitive Risk) are important because credit unions that exited were considered as "closed". This point could cause distortions in the results because the "closed" group may contain both entities whose activities were discontinued, because of financial distress and institutions that were merged or incorporated and did not necessarily experience financial difficulties. In addition, there was a small group of credit unions whose activities ceased, but that discontinuity was not final (i.e. "Suspended"). Therefore, given that credit unions in Brazil may discontinue their operating activities for various reasons and that Cox proportional hazards survival and parametric models do 
not distinguish among different types of exit, but instead consider all exits uniformly, the model of competing risks that includes an indicator variable representing the type of failure is justified. Thus, it is worth considering these factors in the statistical models of survival, and this consideration justifies the use of the model of competing risks that allows different types of disconti- nuity to be distinguished. The results of this analysis are presented in more detail in Table 6.

Table 5 shows the hazard ratios for all the models estimated. The objective was comparing the statistically significant variables in each parametric model studied. The first number for any variable is the coefficient. The numbers in parentheses are the standard errors.

Table 5 Analysis and prediction of discontinuity models (Hazard Ratio Models)

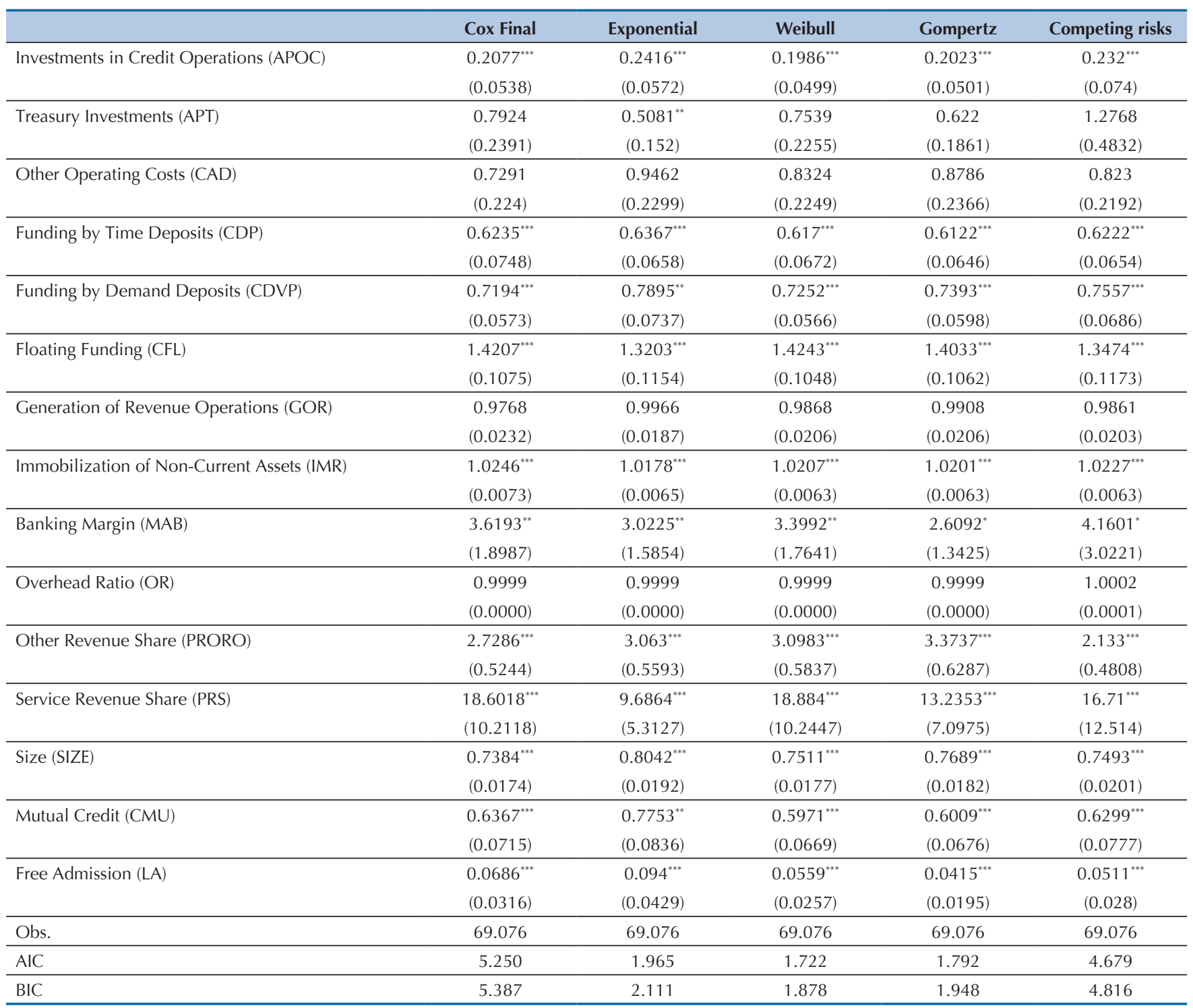

${ }^{*},{ }^{* *}$, and ${ }^{* * *}$ represent the significance at $10 \%, 5 \%$, and $1 \%$, respectively.

Source: Prepared by the authors.

Therefore, by mapping the credit unions whose operations were discontinued within the study period, we were able to identify the factors that determined the various types of market exit using the model of competing risks. Table 6 also shows the model of competing risks, whose purpose is verifying whether different types of exit - extrajudicial liquidation, judicial liquidation, suspension, or closure - may be related to different factors. By analyzing these results, we observed that, despite the large number of credit unions whose activities were dis- continued due to unknown causes (classified as closed), the factors that determine market exit depend on the type of discontinuity.

Table 6 shows different combinations of "Exit Events" and "Competing Events". The objective was comparing the statistically significant variables in each combination. The first number for any variable is the coefficient. The numbers within parentheses are the standard errors. The numbers within brackets are the marginal effects. 


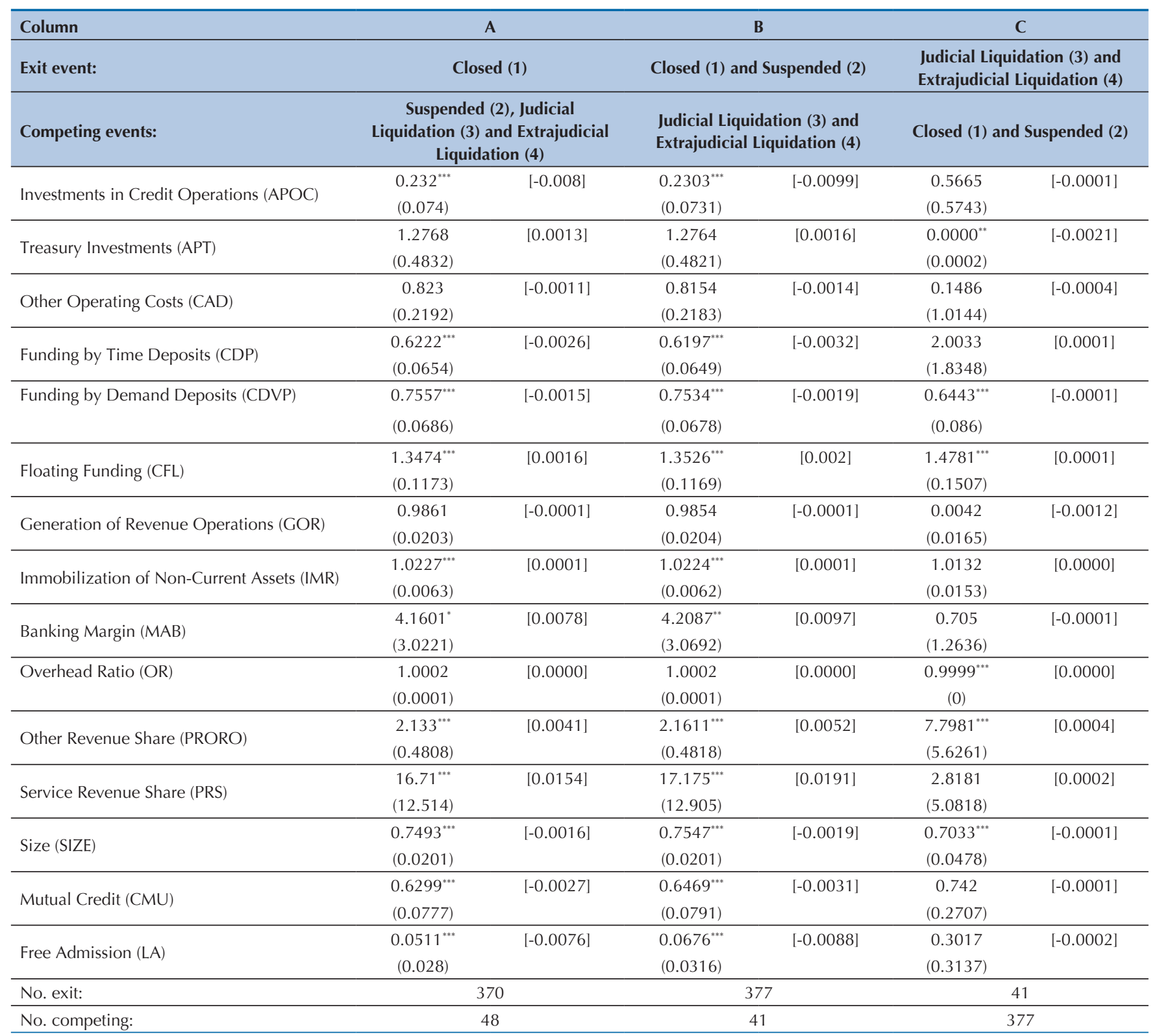

$*^{*}{ }^{* *}$, and ${ }^{* * *}$ represent the significance at $10 \%, 5 \%$, and $1 \%$, respectively. Source: Prepared by the authors.

Different types of discontinuity were also compared to identify distinct factors that either increased or decreased the likelihood of each specific type of exit. In this model, three important variables were considered: the lifespan of each credit union, censorship, and the type of discontinuity (exit). We can observe that combinations of market exit events with different competitive events affect the weight and significance level of the probability of discontinuity. Thus, columns A, B, and C in Table 6 show the results of different combinations and the analysis of results is presented in the next section. Table 6, column A, combines the exit event "Closed" with Competing Risks "Suspended, Judicial Liquidation, and Extrajudicial Liquidation". Column B shows the exit event "Closed and Suspended" and competing event "Judicial Liquidation and Extrajudicial Liquidation". Finally, column C shows the credit unions that closed because of "Judicial Liquidation (3) and Extrajudicial Liquidation (4)", combined with the competing event "Closed (1) and Suspended (2)".
According to the marginal effects presented in Table 6 (the numbers within brackets), the analysis of the closure risk of credit unions suggested that there was a negative relation between an increase in Investments in Credit Operations (A and B), Funding by Time Deposits (A, B, and C), Funding by Demand Deposits (A, B, and $C$ ), and Size (A, B, and C), on the one hand, and the exit from the market of credit unions in Brazil, on the other hand. The variables Floating Funding (A, B and C), Immobilization of Non-Current Assets (A and B), Banking Margin (A and B), Other Revenue Share (A, $B$, and $C$ ), and Service Revenue Share (A and B) had positive associations with higher likelihood of exit. Specifically for model C, Treasury Investments had a negative and Banking Margin had a positive and significant association with the probability of judicial liquidation and extrajudicial liquidation. These results are an indication that different types of exits are determined by different factors. 


\section{ANALYSIS OF RESULTS}

The main result that distinguishes the various types of closure (Table 6) consists of the weight and significance of the coefficients, which show a positive or negative relation between the probability of exit and the various financial ratios. According to the marginal effects shown in Table 6 (the numbers within brackets), the analysis of the closure risk of credit unions indicates that an increase in Funding by Demand Deposits is related to a decrease in the probability of market exit by credit unions in Brazil for all models (models A, B, and $\mathrm{C}$ ). Funding by Time Deposits also has a negative relation to the probability of exit, but only for models $\mathrm{A}$ and $\mathrm{B}$, something which seems to be consistent with expectations, given that funding levels are crucial to the soundness of financial institutions (for model C, the coefficient was not statistically significant).

Floating Funding, Overhead Ratio, and Other Revenue Share have positive relations to the probability of exit. These variables are related to the source of funding of credit unions, and there must be a balance between them for these entities to have sound financial conditions. The positive association between "Floating Funding" and higher risk of failure and the negative relation between "Funding by Demand Deposits" and the risk of failure are puzzling results of this study that must be further investigated.

The results showed that deposit funding is crucial for these entities and that equity growth is needed to maintain the stability of credit unions. Thus, we may infer that credit unions should not be overly dependent on other revenues (Other Revenue Share), because a significant share of this type of revenue could lead to a higher risk of discontinuity. The reduced share of financial intermediation operations in total revenue may be related either to the lower market share of these institutions or to reduced operations with members, and it may signal future operational and financial difficulties.

A similar result was found for Service Revenue Share, which is related to the importance of service revenue in the total revenue. An increase in this indicator is related to an increase in the probability of discontinuity (models A and B), but it is not significantly related to the probability of a "Judicial Liquidation and Extrajudicial Liquidation" type of exit. This finding is significant because lower intermediation is related to the need to increase service revenue, which increases the cost to members and may even discourage them from keeping transactions with the credit union, thus increasing the risk of their exit. The results also confirmed that Treasury Investments have a negative association with the likelihood of closure of these entities (model C of Table 6). Treasury Investments is related to liquidity, which corresponds to the resources that are available for potential investment opportunities and also seems consistent with theoretical predictions.
Thus, another significant factor to be analyzed is Investments in Credit Operations in direct relation to financial intermediation (i.e. fundraising from surplus members to loan to deficit members), which has a negative association with likelihood of exit, according to models A, B, and C, as Table 6 shows. Treasury Investments was found to be non-significant under the exit models regarding "Closed" and "Closed and Suspended" (models A and B), but it had a negative and significant relation in model $\mathrm{C}$; thus, the results demonstrate the greater importance of loans when compared to treasury investments. This result was expected, because although treasury investments are positive for liquidity and important for continuity, they are less profitable than loans. Thus, effective investment management is crucial for the continuity of these entities.

It was also observed that larger credit unions exhibited a negative association with likelihood of closure. This finding is corroborated by our results, which are consistent with theoretical predictions, as well as the need for scale and size in the financial market. Therefore, we may infer that strengthening the inter-cooperative principle by using key cooperatives or further integration by merging or incorporating small credit unions may be alternatives that provide increased operating scale, strengthen the cooperative view, and result, particularly, in a reduced likelihood of discontinuity.

According to Bressan et al. (2013), a negative relation between margin and the probability of insolvency of credit unions should be expected, but their research showed a positive relation between these variables. The findings of this article indicate a positive relation between Banking Margin and the probability of discontinuity (A and B) that is in accordance with Bressan et al. (2013). However, this variable was not significant in relation to "extrajudicial liquidation and judicial liquidation". These variables were significant only in models $A$ and $B$, as shown in Table 6.

The nature of the credit union - Mutual, Free Admission, and Rural - was also important in the survival analysis (for all models presented in Table 5 and for models A and B presented in Table 6). The results showed that Free Admission and Mutual credit unions (models A and B, Table 6) have a lower likelihood of closure than Rural credit unions. The higher probability of exit for a Rural credit union, when compared with other types of credit unions, may be due to the fact that rural credit unions are directly affected by financial agricultural policy, but this point must be further investigated. For the specific type of "Judicial Liquidation and Extrajudicial Liquidation" exit, the type of credit union did not show a significant relation to the probability of exit. In short, based on the findings of the models studied, the determinants of the closure of credit unions in Brazil seem to be related to their in- 
vestment and funding management, the share of other revenues in total revenue, and their size.

Sound funding and investment management were found to be positively related to longevity and negatively related to the risk of market exit by credit unions. This result was confirmed by the finding that demand and time deposit funding adversely affect mortality risk. In addition, it is noteworthy that floating funding, as well as treasury investments, is positively related to higher risk, something which indicates that funding and investment management are significant factors in the management and monitoring of credit unions in Brazil.

Size was a decisive factor both in the survival and longevity of credit unions, corroborating the hypothesis that size is related to economies of scale and scope. Larger credit unions seem to have a greater likelihood of survival. For agricultural cooperatives, size is an important determinant of efficiency; according to Souza, Braga and Ferreira (2011), large agricultural cooperatives are more efficient than small cooperatives, and this result is similar to those of singular credit unions

\section{CONCLUSIONS}

The main objective of this study was investigating and identifying potential financial ratios that are associated with higher or lower risk of credit union discontinuity in Brazil and to verify whether different types of market exit by singular credit unions are related to various factors by using information from active credit unions and their respective financial statements from January 1995 to the second quarter of 2009. The results confirmed that funding and investment management, in addition to size, are positively related to the survival of credit unions in Brazil and that the nature (type) of the credit union is relevant as an explanatory factor.

The model of competing risks showed a significant difference in the determinants of various types of discontinuity. The size of a credit union significantly affects its life expectancy, thus reinforcing the assumption that size is related to economies of scale and driving these institutions to strengthen the cooperative principle of inter-cooperation. The merger of small credit unions and mutual aid through central cooperatives generate economies of scale, higher levels of efficiency, and lower risk of closure.

Because of the duality inherent to the management of such entities (i.e. the use of cooperative principles and the requirements imposed by the market and competition), the need for balance between social and economic performance is a matter of concern. It seems that the model to be adopted for the management of credit unions should vary from that adopted by companies that are not guided by such principles. The results of this study have shown that variables such as banking profitability, return on assets, and credit profitability are not significant in determining the probability of market exit for singular credit unions; thus, the management of credit unions is indeed different from that of banks and it depends on the relation of these institutions to their members. In other words, to explain these results, a higher level of activity and loyalty among credit union members may be associated with better benefits and, therefore, lower profitability. This finding is important for the cooperative movement in Brazil. Based on this study, it is not possible to claim that there is an association between profitability and lower risk of credit union exit (first research question).

The primary distinguishing characteristic of credit unions, as previously noticed, is the relation between operational and social efficiency. Users (i.e. members) of credit unions are also owners and they may influence both the percentage of fees charged and the percentage of surplus to be distributed at the end of the fiscal year. Thus, the provision of services tends to be free for members, interest rates charged on loans tend to be below the average market rates, interest rates regarding return on capital tend to be higher than for other institutions, and the surplus tends to be invested or distributed in current accounts or money, thus maximizing the previous benefits. The main assumption of this study was that the duality inherent to credit unions - cooperative principles versus profitability - could influence the stability of these institutions. However, the results have shown that funding ability and careful investment management are more important than financial efficiency; credit unions that have stronger relations to members tend to be stronger as a whole. However, this statement requires further investigation. A possible explanation for this finding is that a credit union may show some financial inefficiency related to the non-cooperative banking system, with lower returns from lower fees and distributions of surplus, thus generating a positive social effect that not only justifies and facilitates its operation, but also ensures its continuity as a result of its members' loyalty to it and the volume of transactions in which it engages. These results may also imply that a credit union becomes more estranged from its members as it moves towards embracing the rationale of a private bank, thus hindering future operations and increasing the likelihood of its market exit. 
References

Albuquerque Junior, J., \& Ribeiro, E. P. (2001). Avaliação dos indicadores de predição de insolvência bancária no Brasil para os períodos de 1994/95 e 1997/98: uma análise de robustez. In anais do XXVIII Encontro Nacional de Economia (p. 1), Salvador, BA. Retrieved from http://www.anpec.org.br/encontro2001/artigos/200104241.pdf

Altman, E. I. (1968). Financial ratios, discriminant analysis and the prediction of corporate bankruptcy. The Journal of Finance, 23(4), 589-609.

Alves, K. L. F. (2009). Análise de sobrevivência de bancos privados no Brasil (Dissertação de mestrado, Escola de Engenharia de São Carlos, Universidade de São Paulo, São Carlos). Retrieved from http://www. teses.usp.br/teses/disponiveis/18/18140/tde-28102009-103529/

Baer, W., \& Nazmi, N. (2000). Privatization and restructuring of banks in Brazil. The Quarterly Review of Economics and Finance, 40(1), 3-24. doi: $10.1016 /$ s1062-9769(99)00042-3

Ban, U., \& Mazibas, M. (2009). Bank failure prediction with artificial neural networks: a comparative application to Turkish banking system. Iktisat Isletme Ve Finans, 24(282), 27-53. doi: 10.3848/ iif.2009.282.6047

Banco Central do Brasil. (2011). Relatório de inclusão financeira. Brasília, DF: Banco Central do Brasil (n. 2, 2011). Retrieved from http://www bcb.gov.br/Nor/relincfin/RIF2011.pdf

Barron, D. N., West, E., Hannan, M. T. (1994). A time to grow and a time to die: growth and mortality of credit unions in New York City, 1914 1990. The American Journal of Sociology, 100(2), 381-421.

Barroso, M. F. G., \& Bialoskorski Neto, S. (2010). Surplus distribution in San Paulo rural credit cooperatives. Organizações Rurais \& Agroindustriais, 12(2), 290-307.

Bauer, K. J., Miles, L. L., \& Nishikawa, T. (2009). The effect of mergers on credit union performance. Journal of Banking and Finance; 33(12), 2267-2274. doi: 10.1016/j.jbankfin.2009.06.004

Beaver, W. H. (1966). Financial ratios as predictors of failure. Journal of Accounting Research, 4, 71-111.

Bhattacharjee, A., Higson, C., Holly, S., \& Kattuman, P. (2009). Macroeconomic instability and business exit: determinants of failures and acquisitions of UK firms. Economica, 76(301), 108-131. doi: 10.1111/j.1468-0335:2007.00662.x

Braga, M. J., Bressan, V. G. F., Colosimo, E. A., \& Bressan, A. A. (2006). Investigating the solvency of Brazilian credit unions using a proportional hazard model. Annals of Public and Cooperative Economics, 77(1), 83-106. doi: 10.1111/j.1370-4788.2006.00298.x

Bressan, V. G. F., Braga, M. J., Resende Filho, M. A., \& Bressan, A. A. (2013). Brazilian credit union member groups: borrower-dominated, saver-dominated or neutral behavior? Brazilian Administration Review, 10(1), 40-56. doi: 10.1590/S1807-76922012005000008

Bruin, J. (2006). Newtest: command to compute new test. Retrieved from http://www.ats.ucla.edu/stat/stata/ado/analysis/

Canbas, S., Cabuk, A., Kilic, S. B. (2005). Prediction of commercial bank failure via multivariate statistical analysis of financial structures: The Turkish case. European Journal of Operational Research, 166(2), 528546. doi: $10.1016 /$ j.ejor.2004.03.023

Cleves, M., Gould, W. W., Gutierrez, R. G., Marchenko, Y. (2010). An introduction to survival analysis using Stata (3. ed.). Texas: Stata Press.

Cole, R. A., \& Gunther, J. W. (1998).Predicting bank failures: a comparison of on- and off-site monitoring systems Journal of Financial Services Research, 13(2), 103-117. doi: 10.1023/a:1007954718966

Davis, K. (2001). Credit union governance and survival of the cooperative form. Journal of Financial Services Research, 19(2-3), 197-210.

Desai, V. S., Conway, D. G., Crook, J. N., Overstreet, G. A. (1997). Credit-scoring models in the credit-union environment using neural networks and genetic algorithms, IMA Journal of Management Mathematics, 8(4), 323-346. doi: 10.1093/imaman/8.4.323

Dimitras, A.I., Zanakis, S. H., \& Zopounidis, C. (1996). A survey of business failures with an emphasis on prediction methods and industrial applications. European Journal of Operational Research, 90(3), 487-513. doi: 10.1016/0377-2217(95)00070-4

Esteve-Pérez, S., Sanchis-Llopis, A., \& Sanchis-Llopis, J. A. (2010). A competing risks analysis of firms' exit. Empirical Economics, 38(2), 281-304.

Ferguson, C., \& Mckillop, D. G. (2000). Classifying credit union development in terms of mature, transition and nascent industry types. The Service Industries Journal, 20(4), 103-120.

Ferreira, M. A. M., Gonçalves, R. M. L., Braga, M. J (2007). Investigação do desempenho das cooperativas de crédito de Minas Gerais por meio da Análise Envoltória de Dados (DEA). Economia Aplicada, 11(3), 425-445:

Fine, J. P., Gray, R. J. (1999). A proportional hazards model for the subdistribution of a competing risk. Journal of the American Statistical Association, 94(446), 496-497.

Fried, H. O., Knox Lovell, C. A., \& Eeckaut, P. V. (1993). Evaluating the performance of US credit unions. Journal of Banking and Finance, $17(2-3), 251-265$

Fuller, D. (1998). Credit union development: financial inclusion and exclusion. Geoforum, 29(2), 145-157. doi: 10.1016/s0016 7185(98)00009-8

Gimenes, R. M. T., \& Uribe-Opazo, M. A. (2006). Previsão de insolvência de cooperativas agropecuárias por meio de modelos multivariados. Revista FAE, 4(3), 69-78.

Goddard, J., McKillop, D., \&. Wilson, J. O. S. (2009). Which credit unions are acquired? Journal of Financial Services Research, 36(2), 231-252. doi: 10.1007/s10693-009-0055-X

Gu, Z., Lee, C.W. J., \& Rosett, J. G. (2005). What determines the variability of accounting accruals? Review of Quantitative Finance and Accounting, 24(3), 313-334.

Gutiérrez-Nieto, B., Serrano-Cinca, C., \& Mar Molinero, C. (2009). Socia efficiency in microfinance institutions. Journal of the Operational Research Society, 60(1), 104-119. doi: 10.1057/palgrave.jors.2602527

Janot, M. (2001). Modelos de previsão de insolvência bancária no Brasil (Working Papers Series). Brasília, DF: Banco Central do Brasil.

Kaplan, E. L., \& Meier, P. (1958). Nonparametric estimation from incomplete observations. Journal of the American statistical association, 53(282), 45خे-481.

Libby, R. (1975). Accounting ratios and prediction of failure: some behavioral evidence. Journal of Accounting Research, 13(1), 150-161. doi: $10.2307 / 2490653$

Liu, J. (2009). Business failures and macroeconomics factors in the UK Bulletin of Economic Research, 61(1), 47-72. doi: 10.1111/j.14678586.2008.00294.x

Matias, A. B. (1999). Insucesso de grandes bancos privados brasileiros (Tese de Livre-Docência, Faculdade de Economia, Administração e Contabilidade de Ribeirão Preto, Universidade de São Paulo, Ribeirão Preto). Retrieved from http://www.cepefin.org.br/publicados_pdf/ tese_livre_docencia.pdf/

McKillop, D., \& Wilson, J. O. S. (2011). Credit unions: a theoretical and empirical overview. Financial Markets, Institutions and Instruments, 20(3), 79-123.

Ralston, D., Wright, A., Garden, K. (2001). Can mergers ensure the survival of credit unions in the third millennium? Journal of Banking and Finance, 25(12), 2277-2304. doi: 10.1016/s0378-4266(01)00193-5

Soares, M. M., \& Melo Sobrinho, A. D. (2008). O papel do Banco Central do Brasil e a importância do cooperativismo de crédito (2. ed.). Brasília, DF: Banco Central do Brasil.

Souza, U. R., Braga, M., \& Ferreira, M, A. M. (2011). Fatores associados à eficiência técnica e de escala das cooperativas agropecuárias paranaenses. Revista de Economia e Sociologia Rural, 49(3), 573597. Retrieved from http://www.scielo.br/scielo.php?script=sci_ arttext\&pid=S0103-20032011000300003\&lng=en\&tlng=pt.. 10.1590/ S0103-20032011000300003

Spencer, J. E. (1996). An extension to Talor's model of credit union. Review of Social Economy, 54(1), 89-98

Taylor, R. A. (1979). Demand for labour by credit unions. Applied Economics, 11, 333-340

Trindade, M. T., Ferreira Filho, F. A., \& Bialoskorski Neto, S. (2010). Brazilian credit co-operatives and financial banks: a ten-year performance comparison. Journal of Co-operative Studies, 43, 14-22.

Westley, G. D, \& Shaffer, S. (1999). Credit union policies and performance in Latin America. Journal of Banking \& Finance, 23(9), 1303-1329. doi: 10.1016/s0378-4266(99)00006-0

World Council of Credit Unions. (2014). Statistical report. Madison, WI: WOCCU, 2013. Retrieved from http://www.woccu.org/publications/ statreport 